\title{
The Effect of International Remittances on Financial Development: Turkish Experience in the Period of 1974-2019
}

Ayfer ÖZYILMAZ (https://orcid.org/0000-0001-9201-2508), Department of Foreign Trade, Kocaeli University, Turkey; e-mail: ozyilmazayfer@gmail.com

Metin TOPRAK (https://orcid.org/0000-0001-9217-6318), Department of Economics, Ístanbul Sabahattin Zaim University, Turkey; e-mail: metin.toprak@izu.edu.tr

Yüksel BAYRAKTAR (https://orcid.org/0000-0002-3499-4571), Department of Economics, Istanbul University, Turkey; e-mail: ybayraktar@istanbul.edu.tr

\section{Uluslararası İşçi Dövizlerinin Finansal Gelişme Üzerindeki Etkisi: 1974-2019 Dönemi Türkiye Deneyimi}

\begin{abstract}
In this study, workers' remittances on financial development in Turkey are analysed using the Autoregressive Distributed Lag Bound (ARDL) method from 1974 to 2019. In the analysis, the dependent variable, which is the domestic credit to the private sector by banks (percent of GDP), is used as an indicator for financial development. In addition to international workers' remittances, other independent variables include GDP per capita, interest rate, and inflation. International remittances are found to affect financial development positively; however, the effect is slight. In addition, growth affects financial development positively, inflation negatively, and the impact of interest is statistically insignificant.

Keywords $\quad$ Workers' Remittances, Financial System, Financial Development,
ARDL.

JEL Classification Codes: $\quad$ F24, G29, C22.

Öz

Bu çalışmada 1974-2019 dönemi için Türkiye'de işçi dövizlerinin finansal gelişme üzerindeki etkisi ARDL yöntemi ile ele alınmıştır. Analizde, bağımlı değişken olarak finansal gelişmeyi temsilen özel sektöre sağlanan kredilerin GSYİH içerisindeki payı, bağımsız değişkenler olarak ise işçi dövizlerinin yanı sıra büyümeyi temsilen kişi başına reel GSYİH, mevduat faiz oranı ve enflasyon değişkenleri alınmıştır. Analiz bulgularına göre, uluslararası göçmen dövizleri finansal gelişmeyi pozitif etkilemekte, ancak bu etki düşük düzeydedir. Bunun yanı sıra büyüme finansal gelişmeyi pozitif, enflasyon ise negatif etkilemekte ve faizin etkisi ise istatistiksel olarak anlamsızdır.
\end{abstract}

Anahtar Sözcükler $\quad$ : Isşçi Dövizleri, Finansal Sistem, Finansal Gelişme, ARDL. 
Özyılmaz, A. \& M. Toprak \& Y. Bayraktar (2021), "The Effect of International Remittances on Financial Development: Turkish Experience in the Period of 1974-2019”, Sosyoekonomi, 29(49), 181-198.

\section{Introduction}

In the literature, various studies have analysed the effects of international remittances from different perspectives. Remittances have become an essential source of external financing in developing countries. Findings indicate that remittances affect the financial system as well as health, education, employment, and poverty in many ways and thus play a vital role directly and indirectly on national economies. Since the world economy has been more integrated due to financial movements and capital flows, developments in financial markets lead to the improvement of financial infrastructure in many ways, such as the ease of access to funds and the acceleration of the flow of remittances in the developed financial system (Bhattacharya et al., 2018; Nyamongo et al., 2012; Mundaca, 2009).

Remittances are more reliable for receiving countries since they are stable than other international financial resources against economic crises. In addition to the importance of remittances in the financial system, the determining role of financial development on remittances strengthens the relationship between remittances and the financial system (Coon, 2014; Aggarwal et al., 2006; Ratha, 2004). Therefore, many measures are taken by both public and private sectors to integrate remittances into the financial system. The use of money transfer tools such as Western Union and MoneyGram has increased rapidly, besides other domestic and foreign financial institutions in many countries. While investigating the potential of money transfer tools, many countries have established units to attract and promote remittances. While some countries such as China, India, El Salvador, and the Philippines implement government-level policies, some countries concentrate on policies that would accelerate the relationship between remittances and economic development (Bhattacharya et al., 2018).

Remittances are an effective tool in integrating the rural population into the financial system (Cooray, 2012). In other words, remittances are an essential instrument that enables banks to reach individuals who have limited opportunities for accessing financial resources. The stability of remittances makes banks more willing to lend to remittance-receiving households, and this phenomenon positively affects the development of the credit market and increases financial participation. However, even if banks do not lend money to remittance-receiving households, banks' loanable funds increase due to remittance flows. This increase in loanable funds would increase the total credit volume in parallel with the increasing deposits (Coulibaly, 2015; Prakash \& Gounder, 2007; Aggarwal et al., 2006). Especially in high remittances, expected declines in overheads and net interest margins are supposed to positively affect economic growth by providing more credit to the private sector (Cooray, 2012; Misati \& Nyamongo, 2011).

Remittances may affect the financial system negatively if they reduce the demand for individual loans. If remittances do not increase private sector loans and are primarily used to finance government expenditures, the positive effect of remittances on the financial system will be weakened. Also, if remittances are used for consumption or remittancereceiving households prefer alternative investment instruments outside the financial system, 
the effect of remittances on the financial system will be reduced. On the other hand, if remittance-receiving households do not trust the financial system, use remittances directly for consumption, or do not invest money in financial institutions, remittances will not significantly impact financial development (Prakash \& Gounder, 2007; Aggarwal et al., 2006).

Costs are one of the determining factors in the integration of remittances into the financial system. Accordingly, high costs lead remittance-receiving households to prefer unofficial or even illegal transfer channels to transfer remittances (Prakash \& Gounder, 2007). At this point, remittance costs are important; lowering these costs positively affects the remittances through official channels and increases the development of the financial system (Bhattacharya et al., 2018). Therefore, when the financial system develops, remittance-receiving households will have the opportunity to benefit from the financial markets more rapidly and with lower costs (Freund \& Spatafora, 2008).

The two-way dependence effect between remittances and financial development feeds each other, and the interaction of these variables is vital for economic growth. If remittances affect the financial system positively, then the impact on economic growth is also positive but indirect. In this context, remittances offer more financing opportunities to entrepreneurs for human and physical capital investments by expanding the credit volume of the financial system. In such cases, remittances could boost the country's long-term growth through higher rates of capital accumulation. Consequently, if remittances are channelled to and used efficiently by the financial sector, a more significant impact of remittances on growth should be expected. Indeed, a study on low- or middle-income countries in Latin America and the Caribbean supports these findings. According to the study, the impact of financial intermediaries on growth is stronger when interacting with remittances (Mundaca). On the other hand, remittances can have a much more substantial effect on economic growth in countries with relatively underdeveloped financial systems if transferred through the banking system (Giuliano \& Ruiz-Arranz, 2009).

The effect of remittances on financial development is one of the most studied topics in the literature. According to studies suggesting that remittances affect the financial system positively, remittances contribute to the development of the financial system by providing poor households with access to the financial system and increasing the demand for financial products and bank deposits. According to studies emphasizing that remittances have an insignificant or negative effect on financial development, weaknesses in governance, decrease in demand for financial instruments, and the unwillingness of banks to lend are determinants of this effect. One critical point when studying the impact of remittances on the financial system is whether the supply channel or the demand channel is more vital. On the one hand, remittances that are integrated into the financial system increase the banks; fund supply. On the other hand, it can reduce the loan demands of the remittance receivinghouseholds from the financial system. In addition, high remittance costs can also lead to the transfer of remittances outside the financial system, which may cause remittances to be ineffective on financial development. 
One of the critical points here is how much remittances will be used for investments. Indeed, as Karikari et al. (2016) emphasized, only remittances that exceed consumption expenditures contribute to the financial system. Therefore, the fact that these remittances can only finance basic consumption expenditures may cause the remittances to be statistically insignificant on the financial system. In addition, the decrease in the credit demands of the households receiving remittances from the financial system may be determinant in the negative impact of remittances on the financial system. As Brown et al. (2013) emphasized, this leads to a decrease in banking activities and adversely affects financial development. Lack of data required to present all these econometrically brings controversial results regarding the findings.

The literature on the relationship between remittances and financial development is extensive. However, the number of studies demonstrating this relationship is limited for Turkey, and current studies focus more on the causal relationship. On the other hand, this study is critical in understanding how workers' remittances will affect the financial system in countries such as Turkey, where remittances are pretty volatile. This study closes these gaps and contributes to the literature on Turkey.

In this study, the effect of remittances on financial development is investigated using 1974-2019 data in Turkey using ARDL bounds test, which does not require all series to be I (0) or I (1). The rest of the paper is arranged as follows: background, literature, and workers' remittances in Turkey are provided in sections 1, 2, and 3, respectively. In sections 4 and 5 , the econometric method and findings are presented.

\section{Workers' Remittances in Turkey}

In Turkey, the fragility of the financial system increases the importance of remittances for the economy. The inflow pattern of remittances is considerably volatile. The remittances have recently decreased to a low level, and regulatory policies toward financial stability have weakened the interaction between remittances and the financial system. Graph 1 indicates workers' remittances as US\$ and as a percentage of GDP in Turkey.

When remittances are considered chronologically, it is seen that transfers fluctuate depending on many parameters in the Turkish economy. Turkish labour emigration started in the early 1960s, mainly to Western Europe. Two million Turkish workers migrated to approximately 30 countries to find jobs. Remittances began to increase after 1964, reaching a considerable amount and became an important external source of financing for Turkey (Alper, 2005). Due to the small number of migrants and basic settlement costs, workers' remittances were low in the first years. Starting from 1964, migrant workers began to send most revenues to Turkey. The biggest reason for this transfer was that these people were thinking back to Turkey eventually. The initial aim was to save enough money in the shortest possible time. Returning to Turkey as a long-run strategy continued until the second and third generations and later hosting countries has become the permanent places to live in the eyes of immigrants (Suğanlı, 2003). 
Graph: 1

Workers' Remittances (\% of GDP, 1974-2019)
Graph: 2

Workers' Remittances (US\$, 1974-2019)

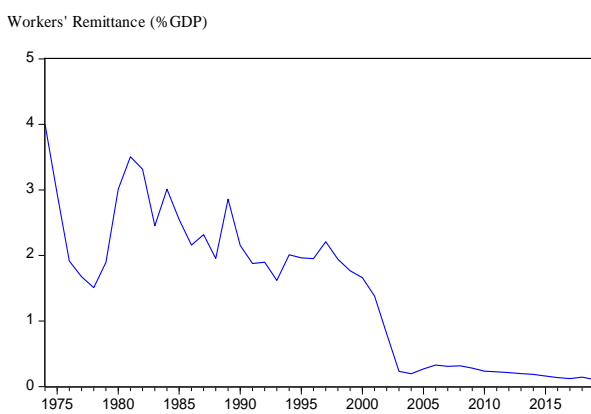

Workers' Remittances (Current US\$)

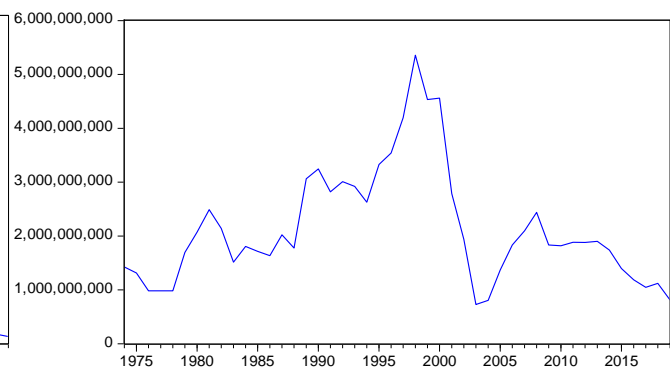

In 1970 and 1974, the Turkish lira's devaluation often also increased workers' remittances for this period. Rising unemployment in Europe decreased remittances transferred to Turkey between 1975 and 1978. Adjusting the exchange rate three times in 1976, twice in 1977, and three times in 1978 did not significantly increase remittances because a significant portion of remittances was traded on the black market (Alper, 2005).

In 1976, a new instrument (foreign currency deposit account with credit letter) was introduced in the Turkish financial system. The Turkish Central Bank started to accept deposits of Turkish workers who live abroad. Then, the inflow of remittances decreased considerably, and this decline was reflected as an increase in deposit accounts. Since commercial banks operating in Turkey started to open branches and representative offices in Germany, increases were seen in remittances during the 1980-1982 period. After these banks began to operate abroad, the inflow of remittances to Turkey became easier (Suğanl, 2003). In this context, from 1961 to the end of 1984, the total remittances transferred to Turkey was $\$ 20$ Billion. Turkey could more easily meet its long-term chronic foreign trade deficit problem with these transfers (Ekin, 2011).

In 1981, Germany allowed Turkish workers to bring their families from Turkey and introduced some incentives in 1983-1984 for the return of Turkish workers who went to Turkey after working a particular time in Germany. These regulations decreased remittances between 1983 and 1988. While Turkish workers in Western Europe transferred remittances to meet their families' basic needs between 1961 and 1981, the aim of the transfer changed. The change in the investment aim is the main reason behind the transfer after 1981 (Alper, 2005).

While exchange rate adjustments were generally a factor that increased remittances in the past, the devaluations in 1994 and 2001 caused instability and negatively impacted remittances. (Alper, 2005). In addition, with the impact of the 1999 earthquake, remittances decreased significantly in parallel with the unfavourable developments in the economy. Indeed, this remittance pattern suggests that remittances are mostly used for investment rather than the sustenance of households (Aydaş et al., 2005). 
Workers' remittances and foreign exchange deposit accounts of the workers abroad at the Turkish Central Bank constituted a significant part of the Central Bank's foreign exchange reserves until the 2000s. These foreign exchange reserves made essential contributions to overcoming the foreign exchange bottleneck in the late 1970s, providing the necessary foreign exchange financing to transition to a market economy in the $1980 \mathrm{~s}$ and executing exchange rate policies until the early 2000s. On the other hand, in parallel with the development of the Turkish financial system and instruments in the 2000s, the options for Turks living abroad to transfer their savings to their homeland in various and safe ways have increased. In addition, consistent monetary and fiscal policies and structural reforms implemented since 2002 have allowed foreign exchange reserves to increase with transactions other than workers' remittances. In addition, since 2003, the Central Bank has started to follow a strategy for the gradual reduction of remittance accounts at the central bank to focus on the main tasks of the Central Bank in the long term. Central Bank provided the opportunity to transfer remittances to the national economy through developing the banking system more effectively. In this context, interest rates of foreign currency deposit accounts with credit letters and foreign exchange super accounts were decreased gradually. Hence, the importance of remittance accounts has been reduced in terms of monetary and exchange rate policies (TCMB, 2013). On the other hand, when focusing on sociocultural reasons for decreasing foreign exchange reserves of Turks living abroad, it is found according to Karagoz (2009) that this decline may be attributed partly to the demographic change in the changing social structures and entrepreneurial skills of Turkish migrants living in Western Europe. The third generation of Turkish immigrants in Western Europe may not be thinking about transferring remittances since they are already citizens of the hosting countries, they live in. Success stories of entrepreneurship, research and higher education have become more audible recently among Western European Turkish immigrants (Hoffman, Makovsky \& Werz, 2020).

Although the workers' remittances started to decrease rapidly in the 2000s, remittances have recently been an essential source of finance. Considering Turkey's current account chronic deficit problem and fragile financial system, workers' remittances still matter in the Turkish economy. Excluding remittances for household consumption and direct investment, how much of these remittances are integrated into the financial system is essential. Another critical issue is whether remittances included in the financial system make the financial system more fragile or positively contribute to financial development. All these points are essential in understanding the net effect of remittances on the economy.

\section{Literature}

The findings on the relationship between remittances and financial development are various. However, in the prevailing opinion, remittances increase financial development. Empirical findings differ widely depending on many factors such as the remittance amount, the distribution of expenditure, the method, and the variables used for measuring financial development. Qiang et al. (2019) emphasized the importance of country-specific conditions in the relationship between remittances and financial development. Brown et al. (2013) 
Özy1lmaz, A. \& M. Toprak \& Y. Bayraktar (2021), “The Effect of International Remittances on Financial Development: Turkish Experience in the Period of 1974-2019”, Sosyoekonomi, 29(49), 181-198.

pointed to the extent of benefiting from banking services and the volume of credit given to the private sector in this relationship. Coulibaly (2015) gave priority to the differences in governance, Fromentin (2017) underlined the level of development of countries, and Giuliano and Ruiz-Arranz (2009) accentuated the level of development of the financial system. Qiang et al. (2019) suggested that the results depend on how much remittances are used for investment or consumption.

Accordingly, Misati et al. (2019) argued that remittances increase savings and accession of remittance-receiving households to the financial system, and these two impacts positively affect financial development in Kenya. In 50 countries with different income levels, Qiang et al. (2019) found that remittances increase financial deepening in all countries and have a more substantial effect on the financial development in low-middleand middle-income countries. Also, when remittances are used for consumption expenditures, they affect financial development adversely. Ugwuegbe et al. (2018) found that remittances increase financial development in the West African Monetary Zone (WAMZ). On the other hand, while remittances positively affect financial deepening, the impact on financial sector productivity is statistically insignificant. Karikari et al. (2016) suggested that remaining remittances from consumption expenditures are used as savings, and these savings lead to financial development by increasing the demand for financial assets in 50 developing countries. However, this finding only occurs in the short term, but the results are the opposite in the long term. Cooray (2012) emphasized that remittances positively affect the financial sector both in quality and quantity in 94 non-OECD countries, Gupta et al. (2009) found that remittances increase financial development in sub-Saharan Africa. According to Gupta et al., remittances contribute to the household budget and allow poor households to access the financial system. According to Giuliano and Ruiz-Arranz (2009), remittances positively affect financial development in countries where the financial system is relatively underdeveloped. Aggarwal et al. (2006) found that remittances increase bank deposits and loans; thus, they positively affect financial development in 99 developing countries. Aggarwal et al. (2011) found similar results in 119 developing countries. Bhattacharya et al. (2018) found a positive effect of remittances on financial development in 57 countries at different income levels. Similar results were found by Kakhkharov and Rohde (2018) for 27 transition economies, by Fromentin (2017) for developing countries except for the low-income group, by Williams (2016) for 45 Sub-Saharan African countries, by Masuduzzaman (2014), and Chowdhur (2011) for Bangladesh, by Ojapinwa and Bashorun (2014) for 32 Sub-Saharan African countries, by Sami (2013) for Fiji, by Nyamongo et al. (2012) for 36 African countries, Ajilore and Ikhide (2012) for 5 SubSaharan Africa countries except for Nigeria, by Heavy et al. (2011) for 9 Middle East-North Africa (MENA) countries, by Oke et al. (2011) for Nigeria, by Shahbaz et al. (2007) for Pakistan. Prakash and Gounder (2007) suggested that remittances have a positive effect but at a low level on Fiji's financial development.

In contrast, Brown et al. (2013) suggested a negative relationship between remittances and financial development in developing countries. According to the study, remittances adversely affect the usage of banking services and do not increase the credit 
volume used by the private sector. Polat (2018) for 29 developing countries and Kumar (2013) found no statistically significant relationship between remittances and financial development for Guyana. According to Olayungbo and Quadri (2019), there is no causality relationship between remittances and financial development in 20 Sub-Saharan African countries. Coulibaly (2015) emphasized that remittances positively affect financial development in 19 Sub-Saharan African countries; however, there is no substantial evidence to support the view that remittances precisely increase financial development in these countries. According to the study, these contradictory results are explained by the differences in governance. Accordingly, weaknesses in governance cause banks to be reluctant to lend, and thus remittances do not increase credit volume, and poor governance causes remittances to be ineffective in financial development.

In Turkey, according to Ege and Şahin (2014), remittances do not have a significant effect on the development of the banking sector, and Akkoyunlu (2013) found no causality relationship between remittances and financial development.

\section{Data and Methodology}

In this study, the relationship between international remittances and financial development is analysed using the ARDL bounds test with annual data for the period 19742019 in Turkey, and a balanced annual panel dataset is used. The domestic credit to the private sector is taken as an indicator representing financial development, and the private sector credit volume as a percentage of GDP is used as the dependent variable in the analysis.

The financial system in Turkey is based on the banking sector. The banking sector composes $90 \%$ of the whole financial system. Credit volume to the private sector is the highest component of the balance sheet of the banking system. Credits to government, public sector securities, and other activities related to the usage of banking sector resources are negligible compared with the private sector credits. The private sector overwhelmingly dominates the Turkish economy. Therefore, the banking sector credit volume to the private sector is taken as a representative for developing the financial sector. To strengthen our empirical results based on previous literature, we include control variables in the relationship between financial development and remittances. Although the effects change according to the country's conditions, the control variables affect the financial system. The model is as follows:

$$
\operatorname{LFIN}_{t}=\beta_{0}+\beta_{1} L R E M_{t}+\beta_{2} L G D P_{t}+\beta_{3} L I N T_{t}++\beta_{4} L I N F_{t}+u_{t}
$$

In equation (1), Domestic credit to the private sector by banks (LFIN) is the dependent variable as a percentage of GDP. This variable is frequently used in measuring financial development. For workers' remittances (LREM), workers' remittance (\% of GDP), which is mostly preferred in the literature, is used. In the model, for other control variables, real GDP per capita (LGDP), deposit interest rate (LINT), and inflation (INF), as the annual change in consumer prices, are used. L indicates the logarithmic transformation of variables. 
The data for the deposit interest rate was taken from the Turkish Republic Strategy and Budget Unit database, and other variables' data were taken from the World Bank's World Development Indicators.

Within the literature, the expected and actual signs of the variables included in the study on financial development are given as in Table 1:

Table: 1

Expected and Actual Signs of Variables on Financial Development

\begin{tabular}{|c|c|c|}
\hline Variables & Expected Impact of Variables on Financial Development & Actual Effect of Variables on Financial Development \\
\hline Workers' Remittance & $(-),(+)$ and insignificant & $(+)$ \\
\hline GDP per capita & $(+)$ and insignificant & $(+)$ \\
\hline Interest Rate & $(-),(+)$ and insignificant & insignificant \\
\hline Inflation & $(-)$ and insignificant & $(-)$ \\
\hline
\end{tabular}

The studies, which used the model we employed here, found contradictory results regarding the impact of workers' remittances on financial development as portrayed in the literature review above. The unique features of a country or country groups are determining in obtaining these contradictory findings. However, we predicted a positive impact of remittances on financial development or a statistically insignificant effect on Turkey. The low level of remittances in quantity, especially recently, and the lower share of remittances in total foreign exchange reserves in the whole banking system were determining factors while constructing the hypothesis.

A vital factor to be considered while running the model is the impact of economic growth on financial development. The general understanding is that economic growth increases financial development. In this context, as Robinson (1952) emphasized in her demand-following hypothesis, the development of the real sector in the country increases the need for the financial system, and this need leads to financial development. On the other hand, it is difficult to affirm a net effect of interest rate on domestic credit to the private sector by banks, which is an indicator of financial development in the model, because rising interest rates affect credit supply and demand in different directions. The effect of interest rate was found statistically insignificant in our study. Therefore, as Chowdhury (2011) emphasized, the impact of interest on financial development varies by country. When we consider the effect of high inflation in Turkey, we see inflation is expected to affect financial development negatively. In this sense, as Boyd et al. (2001) emphasized, rising inflation decreases real benefit from investment in financial assets. Then this decrease leads to fluctuations in the supply of and demand for financial assets and thus adversely affects the financial system.

The ARDL bounds test method used in this study does not require all series to be I (0) or I (1). On the other hand, ARDL ensures that the long-term coefficients are consistent and unbiased. The error correction model can be calculated from ARDL, and it can be determined how long the imbalances that occur in the short term are eliminated in the long term (Pekmezci \& Karayel, 2018; Yamak \& Korkmaz, 2007). In the ARDL bounds test, the 
Unrestricted Error Correction Model is established firstly. The model is adapted to our study as follows:

$$
\begin{aligned}
& \Delta L F I N_{t}=\beta_{0}+\sum_{i=1}^{q} \beta_{1 i} \Delta L F I N_{t-i}+\sum_{i=0}^{k} \beta_{2 i} \Delta L R E M_{t-i}+\sum_{i=0}^{l} \beta_{3 i} \Delta L G D P_{t-i}+ \\
& \sum_{i=0}^{m} \beta_{4 i} \Delta L I N T_{t-i}+\sum_{i=0}^{n} \beta_{5 i} \Delta L I N F_{t-i}+\beta_{6} L F I N_{t-1}+\beta_{7} L R E M_{t-1}+\beta_{8} L G D P_{t-1}+ \\
& \beta_{9} L I N T_{t-1}+\beta_{10} L I N F_{t-1}+u_{t}
\end{aligned}
$$

In equation (2), $q, \mathrm{k}, \mathrm{l}, \mathrm{m}, \mathrm{n}$ indicates the optimal lag lengths, and $\mathrm{u}_{\mathrm{t}}$ is the error term. Equation (3) shows the error correction model. The model reveals whether these deviations disappear if the series acting together in the long run and deviate from the balance in the short run. The model reveals that if the deviations disappear, it converges to the long-term equilibrium value again in how long it takes. In addition, the error correction term coefficient $(\omega)$ indicates the convergence speed of the series to the equilibrium value. The fact that the error correction term $(\omega)$ coefficient is positive indicates that the effect of the shock on one of the series is not extinguished, and the series has moved away from its equilibrium value. However, the fact that this term is negative and statistically significant indicates that the deviations occurring in the short term between the series acting together disappear in the long-term, and the series converges to the long-term equilibrium value again (Tar1, 2011). The error correction model is as follows:

$$
\begin{aligned}
& \Delta \operatorname{LFIN}_{t}=\beta_{0}+\sum_{i=1}^{q} \beta_{1 i} \Delta \operatorname{LFIN}_{t-i}+\sum_{i=0}^{k} \beta_{2 i} \Delta L R E M_{t-i}+\sum_{i=0}^{l} \beta_{3 i} \Delta L G D P_{t-i}+ \\
& \sum_{i=0}^{m} \beta_{4 i} \Delta \operatorname{LINT}_{t-i}+\sum_{i=0}^{n} \beta_{5 i} \Delta \operatorname{LINF}_{t-i}+\omega E C M_{t-1}+\varepsilon_{t}
\end{aligned}
$$

In equation (3) $\omega E C M_{t-1}$ that refers to the error correction term, is the lagged error correction term obtained from the long-run equilibrium relationship.

As the first step of the ARDL cointegration method, F-statistics or Wald statistics are used for testing the significance of the bounds test. The bounds test indicates whether there is cointegration between series. $\mathrm{H}_{0}$ hypothesis for the bounds test indicates no cointegration, which means that the coefficients together are insignificant. The hypothesis established for the bounds test is as follows:

$$
\begin{aligned}
& H_{0}: \beta_{6}=\beta_{7}=\beta_{8}=\beta_{9}=\beta_{10}=0 \\
& H_{1}: \beta_{6} \neq \beta_{7} \neq \beta_{8} \neq \beta_{9} \neq \beta_{10} \neq 0
\end{aligned}
$$

\section{Empirical Result}

In the empirical analysis, Augmented Dickey-Fuller (ADF) and Phillips Perron (PP) unit root tests were used first to determine the stationarity of the series, and the results are presented in Table 2. For ADF and PP unit root tests, the $\mathrm{H}_{0}$ hypothesis indicates a unit root in the series.

In Table 2, according to ADF and PP unit root tests, all variables are not stable at different levels. When the first difference of all variables is taken, it is seen that the series are statistically significant at the $1 \%$ significance level. Hence, the $\mathrm{H}_{0}$ hypothesis was 
rejected. That is, all series do not contain the unit root at the first difference; thus, the series is stationary in the first difference.

Table: 2

\section{ADF and PP Unit Root Test Results}

\begin{tabular}{|c|c|c|c|c|c|c|c|}
\hline & & \multicolumn{3}{|c|}{ ADF } & \multicolumn{3}{|c|}{ PP } \\
\hline & & & Level & 1st difference & & Level & 1st difference \\
\hline \multicolumn{2}{|l|}{ Variables } & Intercept & Intercept + Trend & Intercept & Intercept & Intercept + Trend & Intercept \\
\hline \multicolumn{2}{|l|}{ LFIN } & $0.11320[0]$ & $-1.6644[4]$ & $-4.8698 *[0]$ & $-0.1260[2]$ & $-1.4651[4]$ & $-4.7770 *[7]$ \\
\hline \multicolumn{2}{|l|}{ LREM } & $-0.2094[0]$ & $-2.4344[1]$ & $-4.9116^{*}[0]$ & $-0.4016[2]$ & $-1.9627[2]$ & $-4.6971 *[6]$ \\
\hline \multicolumn{2}{|l|}{ LGDP } & $0.4030[0]$ & $-2.1406[0]$ & $-6.3714 *[0]$ & $0.4414[3]$ & $-2.2067[1]$ & $-6.3692 *[2]$ \\
\hline \multicolumn{2}{|l|}{ LINT } & $-2.3188[6]$ & $-1.9676[0]$ & $-5.4588 *[0]$ & $-1.5025[3]$ & $-1.9676[0]$ & $-5.4270 *[2]$ \\
\hline \multicolumn{2}{|l|}{ LINF } & $-1.1799[0]$ & $-1.5787[4]$ & $-5.8688 *[0]$ & $-1.2622[3]$ & $-1.9964[5]$ & $-5.8483 *[7]$ \\
\hline \multirow{3}{*}{ Test critical values: } & $1 \%$ & -3.5847 & -4.1985 & -3.5885 & -3.5847 & -4.1756 & -3.5885 \\
\hline & $5 \%$ & -2.9281 & -3.5236 & -2.9297 & -2.9281 & -3.5130 & -2.9297 \\
\hline & $10 \%$ & -2.6022 & -3.1929 & -2.6030 & -2.6022 & -3.1868 & -2.6030 \\
\hline
\end{tabular}

Notes: In the ADF unit root test, the maximum lag length is taken as 9. The values in [ ] indicate the optimal lag length using the Akaike information criterion. In the PP test, the optimal lag length is determined by Barlett Kernel (default) the spectral estimation method and Newey-West Bandwith (automatic selection). Values in [ ] represent the bandwidth which was determined using the Newey-West Criterion. *,**, *** indicates at 1\%, 5\%, 10\% significance levels, respectively.

In addition to traditional unit root tests, Zivot-Andrews (1992) unit root test was used to examine whether there were any structural breaks in the series. Model A allows a structural break in constant; Model B allows a structural break in trend; Model C allows structural break in constant and trend. In the Zivot-Andrews unit root test with a structural break, the null hypothesis is that the series contains a unit root without a structural break. The alternative hypothesis is that the series is stationary with a single break. Zivot-Andrews unit root test results are given in Table 3.

Table: 3

\section{Zivot-Andrews Unit Root Test Results}

\begin{tabular}{|c|c|c|c|c|}
\hline \multicolumn{2}{|l|}{ Variables } & Model A & Model B & Model C \\
\hline \multicolumn{2}{|l|}{ LFIN } & $-3.343[1](2005)$ & $-4.313 * * *[1](2003)$ & $-4.920 * * *[1](1998)$ \\
\hline \multicolumn{2}{|l|}{ LREM } & $-5.252 * *[1](2002)$ & $-3.890[1](1995)$ & $-6.340 *[1](2002)$ \\
\hline \multicolumn{2}{|l|}{ LGDP } & $-3.286[0](2011)$ & $-3.401[0](1981)$ & $-3.519[0](1999)$ \\
\hline \multicolumn{2}{|l|}{ LINT } & $-3.671[0](2002)$ & $-3.109[0](1981)$ & $-2.274[0](1982)$ \\
\hline \multicolumn{2}{|l|}{ LINF } & $-4.864 * *[0](2003)$ & $-2.072[0](1989)$ & $-3.879[0](2003)$ \\
\hline \multirow{3}{*}{ Test critical values: } & $1 \%$ & -5.34 & -4.93 & -5.57 \\
\hline & $5 \%$ & -4.80 & -4.42 & -5.08 \\
\hline & $10 \%$ & -4.58 & -4.11 & -4.82 \\
\hline
\end{tabular}

Akaike information criterion was used. [] shows the optimal lag length, and () indicates the break date. *,**,*** indicates at 1\%, 5\%, 10\% significance levels, respectively.

According to the Zivot-Andrews unit root test results, the null hypothesis is rejected in Model B and Model C for the variable LFIN, because the test statistic is greater than the critical value at the $10 \%$ significance level. Therefore, being greater than the critical value indicates that the series is stationary with a single break at the $10 \%$ significance level. For the variable LREM, the null hypothesis is rejected at the 5\% significance level in Model A and the $1 \%$ significance level in Model C, since the calculated test statistic is greater than the critical value, and it is concluded that the series is stationary with a single break. For LGDP and LINT variables, the null hypothesis cannot be rejected since the test statistics are 
not greater than the critical values in any model. Therefore, the series contains a unit root without a structural break. On the other hand, the LINF variable is stationary with a single break only according to the Model A results.

When looking at the breakup dates for workers' remittances, 2002 is seen as the date of breakup in both Model A and Model C. The most important reason for the breakup in this year is the classification change in the balance of payments, and because of the new calculation method, remittances are found to be 2/3 incomplete (Artukoğlu, 2005). When looking at the breakup dates of the financial development variable, it is seen that the years 1998 and 2003 come to the fore. The breakup in 1998 was based on the economic crises of South East Asia and Russia in 1997-1998. The Iraq War, which broke out at the beginning of 2003, was a determinant in the contraction in credit supply and demand this year due to the uncertainties it caused. The crises in this period decreased the loans given to the private sector due to the contraction in the real sector and the decrease in demand.

The method giving the smallest information criterion value was chosen to determine the optimal lag length. Since it gives the smallest value and the results, the Akaike information criterion was chosen. The findings are presented in Table 4.

\section{Table: 4}

\section{Selection of Information Criteria}

\begin{tabular}{|c|c|}
\hline Information Criteria & Value \\
\hline Akaike & -1.925 \\
\hline Schwarz & -1.214 \\
\hline Hannan-Quinn & -1.666 \\
\hline Durbin-Watson & 2.212 \\
\hline
\end{tabular}

After determining which information criteria to use in determining the optimum lag length, the ARDL bounds test was used for the cointegration relationship between the variables. The bounds test results are given in Table 5 according to the sample size.

Table: 5

The ARDL Bounds Test

\begin{tabular}{|c|c|c|c|c|}
\hline Test Statistic & & Value & & $\mathbf{k}$ \\
\hline F-statistic & & 5.44 & & 4 \\
\hline \multicolumn{5}{|l|}{ Significance } \\
\hline & $n=45$ & $\mathrm{n}=1000$ & $n=45$ & $n=1000$ \\
\hline $10 \%$ & 2.40 & 2.2 & 3.35 & 3.09 \\
\hline $5 \%$ & 2.85 & 2.56 & 3.91 & 3.49 \\
\hline $1 \%$ & 3.89 & 3.29 & 3.35 & 4.37 \\
\hline
\end{tabular}

In the ARDL bounds test results, the calculated F-statistic value is less than the critical value, i.e., there is no cointegration relationship between the series. If the F-statistic value is greater than the critical value, it is concluded that there is a cointegration relationship between the variables. If the sample size is asymptotically 1000, the calculated F test statistic is greater than the lower and upper limit values at the $1 \%$ significance level; therefore, the $\mathrm{H}_{0}$ hypothesis indicates that there is no cointegration and is rejected. If the sample size is taken as 45 , it is seen that there is a cointegration relationship between the series at the $5 \%$ 
significance level. According to the results of the bounds test, the F-statistic value is greater than the bounds values, and $\mathrm{H}_{0}$ is rejected. It is concluded that there is a cointegration relationship between the variables. After determining the cointegration relationship, longrun relationships between variables were analysed, and the results are presented in Table 6.

Table: 6

ARDL (5, 0, 1, 5, 1) Long-Run Coefficients

\begin{tabular}{|c|c|c|c|c|}
\hline Variable & Coefficient & Std. Error & t-Statistic & Prob. \\
\hline LREM & 0.2531 & 0.1105 & 2.28 & 0.0314 \\
\hline LGDP & 1.5795 & 0.2653 & 5.95 & 0.0000 \\
\hline LINT & -0.1502 & 0.1167 & -1.28 & 0.2103 \\
\hline LINF & -0.2564 & 0.1485 & -1.72 & 0.0971 \\
\hline $\mathrm{C}$ & -9.7102 & 2.1988 & -4.41 & 0.0002 \\
\hline
\end{tabular}

According to $\operatorname{ARDL}(5,0,1,5,1)$ long-run estimation results, there is a statistically significant and positive relationship between financial development and remittances at the level of 5\% significance. Accordingly, a 1\% increase in remittances increases financial development by $0.25 \%$. Also, there is a statistically significant and positive relationship between GDP per capita and financial development at a level of $1 \%$ significance; that is, a $1 \%$ increase in GDP per capita increases financial development by $1.57 \%$. There is a statistically significant and negative relationship between inflation and financial development that exists at a level of $10 \%$ significance. Accordingly, a $1 \%$ increase in inflation reduces financial development by $0.25 \%$. There is no statistically significant relationship between the interest rate and financial development.

In Table 7, the Error Correction model results are presented. Accordingly, there is no autocorrelation and heteroscedasticity in the model.

Table: 7

\section{Error Correction Model Results}

\begin{tabular}{|c|c|c|c|c|}
\hline Variable & Coefficient & Std. Error & t-Statistic & Prob. \\
\hline $\mathrm{D}(\mathrm{LFIN}(-1))$ & 0.1351 & 0.1137 & 1.18 & 0.2465 \\
\hline $\mathrm{D}($ LFIN (-2)) & -0.1059 & 0.1262 & -0.83 & 0.4098 \\
\hline D(LFIN (-3)) & -0.1923 & 0.1226 & -1.56 & 0.1297 \\
\hline D(LFIN (-4)) & 0.3912 & 0.1054 & 3.71 & 0.0011 \\
\hline $\mathrm{D}($ LGDP) & 2.5116 & 0.3607 & 6.96 & 0.000 \\
\hline $\mathrm{D}(\mathrm{LINT})$ & -0.1502 & 0.0674 & -2.22 & 0.0357 \\
\hline $\mathrm{D}(\operatorname{LINT}(-1))$ & 0.3238 & 0.0674 & 4.80 & 0.0001 \\
\hline D(LINT (-2)) & 0.1516 & 0.0608 & 2.49 & 0.0199 \\
\hline D(LINT (-3)) & 0.1898 & 0.0629 & 3.01 & 0.0060 \\
\hline D(LINT (-4)) & 0.0823 & 0.0520 & 1.58 & 0.1265 \\
\hline $\mathrm{D}$ (LINF) & 0.0392 & 0.0592 & 0.66 & 0.5141 \\
\hline ECM(-1) & -0.5362 & 0.0853 & -6.28 & 0.0000 \\
\hline & & Diagnostics Tests & & \\
\hline & & Test statistics & Prob & \\
\hline R-squared & & 0.78 & & \\
\hline \multicolumn{2}{|l|}{ Durbin-Watson statistic } & 2.21 & & \\
\hline F-statistic & & 4.6020 & 0.0004 & \\
\hline \multicolumn{2}{|l|}{ Breusch-Godfrey LM } & 0.90 & 0.3526 & \\
\hline Ramsey Test & & 0.85 & 0.3989 & \\
\hline \multicolumn{2}{|l|}{ Jargue-Bera Normality Test } & 4.55 & 0.1027 & \\
\hline \multicolumn{2}{|l|}{ Breusch-Pagan Test } & 1.46 & 0.1929 & \\
\hline \multicolumn{2}{|l|}{$\mathrm{ARCH}$} & 0.02 & 0.8738 & \\
\hline
\end{tabular}


According to the Error Correction Model, the error correction coefficient (ECM-1) is negative and statistically significant, as expected. The deviations occurring in the short term among the series that move together in the long run disappear, and all series converge back to the long-term equilibrium value. In addition, deviations that occur in the short term disappear after about two periods.

CUSUM and CUSUMSQ graphs were used to determine whether the model coefficients are stable or not, and results are presented in Figure 3. Accordingly, CUSUM and CUSUMSQ statistics indicate that the coefficients are stable in the ARDL bounds testing approach.

Figure: 3

\section{Plots of CUSUM and CUSUMSQ Statistics for Coefficient Stability}

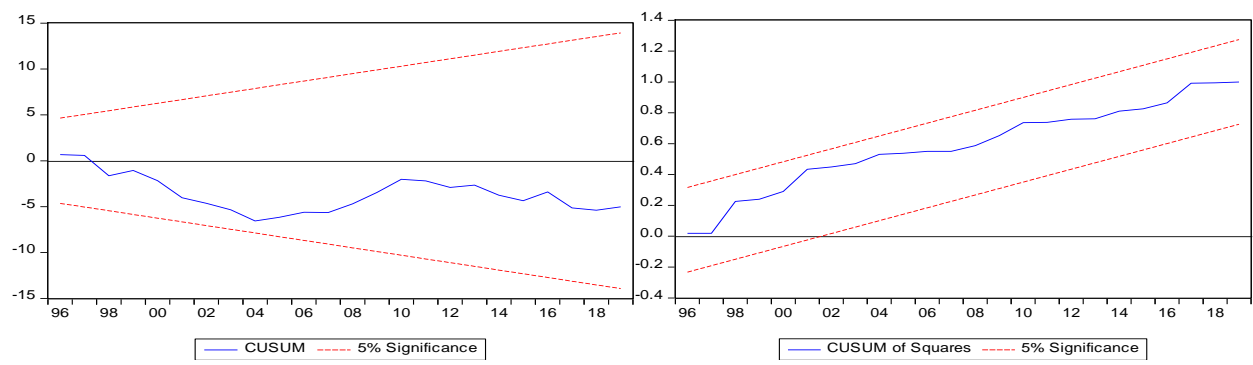

\section{Conclusion}

International workers' remittances enable both low-income households to access the financial system and increase the number of loanable funds by increasing the number of financial resources. The amount of loanable funds positively affects financial development when used in productive areas. The level of financial development affects not only the financial markets but also the national economy in many aspects, such as portfolio investments, foreign direct investments, consumption, and employment. In this context, considering the determining role of financial development on the national economy, the role of international remittances in the financial system is multifaceted.

The impact of international remittances on financial markets occurs through different channels. These channels can be expressed as follows: (i) Providing ease of access to funds; (ii) Acting as an automatic stabilizer to prevent crises from deepening during a recession; (iii) Increasing financial participation by integrating the rural population who has problems accessing the financial system; and (iv) Increasing the number of loanable funds by being both a stable foreign resource and a component of loan supply. However, these positive results are possible only if international remittances remain within the financial system. In contrast, in the case of the following, the positive effects of remittances would weaken. The use of remittances for consumption, the underdevelopment of the financial system, the low prevalence of the financial system, the problem of trust in the financial system, and finally, 
the tendency toward unofficial transfer methods because of the high cost of financial transfers are the main factors in the weakening. Within this framework, lower transaction costs of international remittances and simplification of regulations would motivate international remittances to be transferred and kept in the financial system. Considering the insufficient resources of developing countries, we see that international remittances are critical in the national financial system.

In this study, the effect of international workers' remittances on the Turkish financial system for the period of 1974-2019 was analysed using the ARDL bounds test. In addition to remittances, GDP per capita, interest rate, and inflation are also used as explanatory variables in the analysis. The findings indicate that international workers' remittances affect financial development positively. However, it is found that this effect is small. The low level of this effect can be partly attributed to the decrease of remittances after 2000 in Turkey. The measures taken to ensure financial stability in 2002 and afterward led to the strengthening of the financial system. It is seen that structural reforms were more determinant in developing the financial system than to immigrants. Therefore, the share of remittances in the national economy determines whether the impact is strong or weak. For example, Bugamelli and Paternò (2009) argued that the contribution of remittances to the financial system is much stronger when remittances have a 3\%-4\% of GDP. In Turkey, especially recently, this ratio was realized but at a low level.

On the other hand, the effects of other explanatory variables on financial development are consistent with the findings in the literature. While economic growth positively affects financial development, the effect of interest rate on financial development is statistically insignificant. Chowdhury (2011) emphasizes the impact of interest rates on financial development differs between countries. Our analysis indicates that inflation negatively affects financial development. According to Boyd et al., (2001), increasing inflation decreases real income from investment in financial assets; and then leads to fluctuations in the supply of and demand for financial assets adversely affecting the financial system.

Integrating remittances into the financial system is important for the effectiveness of the financial system. Because remittances are more stable than foreign direct and portfolio investments into the financial system, especially in Turkey, which has frequently faced exchange rate crises, remittances should be turned into an important policy tool in strengthening the financial system.

In this context, we can list the policies that can be used to integrate remittances into the financial system as follows: i) Focusing on structural reforms that will enable immigrants to integrate deposits into the banking system, ii) Ensuring financial stability and thus establish trust in the banking system, iii) Implementing a different interest policy to attract remittances into the country, iv) Minimizing banking costs, v) Facilitating remittance flows by promoting market-friendly regulations. 
Özyılmaz, A. \& M. Toprak \& Y. Bayraktar (2021), "The Effect of International Remittances on Financial Development: Turkish Experience in the Period of 1974-2019”, Sosyoekonomi, 29(49), 181-198.

\section{References}

Aggarwal, R. \& A. Demirguc-Kunt \& M.S. Martinez-Peria (2006), "Do Workers' Remittances Promote Financial Development?”, Policy Research Working Paper, 3957, World Bank Group, Washington, D.C.

Ağır H. \& M. Kar \& Ş. Nazlıglu (2011), "Do Remittances Matter for Financial Development in the MENA Region? Panel Cointegration and Causality Analysis", Empirical Economics Letters, 10(5), 449-456.

Ajilore, T. \& S. Ikhide (2012), “A Bounds Testing Analysis of Migrants Remittances and Financial Development in Selected Sub-Sahara African Countries", Review of Finance and Banking, 4(2), 79-96.

Akkoyunlu, Ş. (2013), "Remittances and Financial Development: Is There a Direct Link? Evidence from Turkish Data", Journal of Emerging Markets, 18(1), 1-15.

Alper, A.M. (2005), "İşçi Dövizlerini Belirleyen Makro Ekonomik Etkenler: Türkiye Örneği”,, Uzmanlık Yeterlilik Tezi, Turkiye Cumhuriyeti Merkez Bankasi İşçi Dövizleri Genel Müdürlüğü, Ankara.

Anzoategui, D. \& A. Demirgüç-Kunt \& M.S. Martínez-Pería (2014), "Remittances and Financial Inclusion: Evidence from El Salvador”, World Development, 54 (2014), 338-349.

Artukoğlu, O.S. (2005), "Yurtdışı İşçi Tasarruflarının Türkiye Cumhuriyet Merkez Bankası, Banka Sistemi ve Türkiye Ekonomisi Üzerine Etkileri”, Ankara, Türkiye Cumhuriyet Merkez Bankası İşçi Dövizleri Genel Müdürlüğü, Uzmanlık Yeterlilik Tezi, Ankara.

Aydas, O.T. \& K. Metin-Ozcan \& B. Neyapti (2005), "Determinants of Workers' Remittances: The Case of Turkey", Emerging Markets Finance and Trade, 41(3), 53-69.

Bhattacharya, M. \& J. Inekwe \& R.S. Paramati (2018), "Remittances and Financial Development: Empirical Evidence from Heterogeneous Panel of Countries", Applied Economics, 50(38), 4099-4112.

Boyd, J.H. \& R. Levine \& B.D. Smith (2001), "The Impact of Inflation on Financial Sector Performance", Journal of Monetary Economics, 47(2), 221-248.

Brown, P.C. \& F.C. Richard \& G. Fayad (2013), "Migrants Remittances and Financial Development: Macro and Micro-Level Evidence of a Perverse Relationship", The World Economy, 36(5), 636-660.

Bugamelli, M. \& F. Paternò (2009), “Do workers' Remittances Reduce the Probability of Current Account Reversals?”, World Development, 37(12), 1821-1838.

Chowdhury, M.B. (2011), "Remittances Flow and Financial Development in Bangladesh", Economic Modelling, 28(6), 2600-2608.

Coon, M. (2014), "Financial Development and the end-use of Migrants' Remittances", IZA Journal of Labor and Development, 3(1), 1-7.

Cooray, A. (2012), "Migrant Remittances, Financial Sector Development and the Government Ownership of Banks: Evidence from a Group of non-OECD Economies", Journal of International Financial Markets, Institutions and Money, 22(4), 936-957.

Coulibaly, D. (2015), "Remittances and Financial Development in Sub-Saharan African Countries: A System Approach", Economic Modelling, 45(2015), 249-258.

Ege, İ. \& S. Şahin (2014), "Doğrudan Yabancı Sermaye Yatırımı, İşçi Dövizleri ve Bankacılık Sektörü Gelişimi: Türkiye Örneği”, Finans Politik ve Ekonomik Yorumlar, 51(598), 9-17. 
Ekin, N. (2011), "İşçi Dövizleri ve Sanayileşme”, İstanbul Üniversitesi İktisat Fakültesi Mecmuası, 42, 1-4.

Freund, C. \& N. Spatafora (2008), "Remittances, Transaction Costs and Informality", Journal of Development Economics, 86(2), 356-66.

Fromentin, V. (2017), "The Long-run and Short-run Impacts of Remittances on Financial Development in Developing Countries", The Quarterly Review of Economics and Finance, 66(2017), 192-201.

Giuliano, P. \& M. Ruiz-Arranz (2009), "Remittances, Financial Development and Growth”, Journal of Development Economics, 90(1), 144-152.

Gupta, S. \& C.A. Pattillo \& S. Wagh (2009), "Effect of Remittances on Poverty and Financial Development in Sub-Saharan Africa", World Development, 37(1), 104-115.

Hoffman, M. \& A. Makovsky \& M. Werz (2020), The Turkish Diaspora in Europe: Integration, Migration, and Politics, Center for American Progress.

Kakhkharov, J. \& N. Rohde (2018), "Remittances and Financial Development in Transition Economies", Empirical Economics, 12(4), 1-33.

Karagöz, K. (2009), "Workers' Remittances and Economic Growth: Evidence from Turkey”, Journal of Yaşar University, 4(13), 1891-1908.

Karikari, N.K. \& S. Mensah \& S.K. Harvey (2016), "Do Remittances Promote Financial Development in Africa?", Springer Plus, 5(1), 1-21.

Kevin, W. (2016), "Remittances and Financial Development: Evidence from Sub-Saharan Africa", African Development Review, 28(3), 357-367.

Kumar, R.R. (2013), "Remittances and Economic Growth: A Study of Guyana”, Economic Systems, 37(3), 462- 472.

Masuduzzaman, M. (2014), "Workers' Remittance Inflow, Financial Development and Economic Growth: A Study on Bangladesh", International Journal of Economics and Finance, 6(8), 247-267.

Misati, R.N. \& A. Kamau \& H. Nassir (2019), "Do Migrant Remittances Matter for Financial Development in Kenya?", Financial Innovation, 5(1), 1-25.

Misati, R.N. \& E.M. Nyamongo (2011), "Financial Development and Private Investment in SubSaharan Africa", Journal of Economics and Business, 63(2), 139-151.

Mundaca, B.G. (2009), "Remittances, Financial Market Development and Economic Growth: the case of Latin America and the Caribbean", Review of Development Economics, 13(2), 288-303.

Narayan, P.K. \& S. Narayan (2005), "Estimating Income and Price Elasticities of Imports for Fiji in a Cointegration Framework", Economic Modelling, 22(3), 423-438.

Nyamongo, E.M. et al. (2012), "Remittances, Financial Development and Economic Growth in Africa", Journal of Economics and Business, 64(3), 240- 260.

Ojapinwa, T.V.\& O.T. Boshorun (2014), “Do Workers' Remittances Promote Financial Development in Sub-Sahara Africa Countries", International Journal of Financial Research, 5(2), 151-159.

Oke, B. et al. (2011), "Impact of Workers' Remittances on Financial Development in Nigeria", International Business Research, 4(4), 218-225. 
Olayungbo, D.O. \& A. Quadri (2019), "Remittances, Financial Development and Economic Growth in Sub-Saharan African Countries: Evidence from a PMG-ARDL Approach", Financial Innovation, 5(9), 1-25.

Pekmezci, A. \& K. Karayel (2018), "Finansal Gelişme ile Ekonomik Büyüme İlişkisinin BIST100 Üzerinden ARDL Analizi”, Yönetim ve Ekonomi Araştırmaları Dergisi, 16(4), 428-443.

Pesaran, M.H. \& Y. Shin \& R.J. Smith (2001), "Bounds Testing Approaches to The Analysis of Level Relationships", Journal of Applied Econometrics, 16(3), 289-326.

Polat, B. (2018), “The Impact of Workers' Remittances on Financial Market Development: A Case Study for Developing Countries", Journal of Business Research Turk, 10(2), 27-36.

Prakash, N.N. \& R. Gounder (2007), “The Role of Remittance in Financial Development in Fiji”, Fijian Studies: A Journal of Contemporary Fiji, 9(2), 123-136.

Qiang, S. \& A. Khurshid, \& A.C. Calin \& K. Khan (2019), "Do Remittances Contribute to the Development of Financial Institutions? New Evidence from the Developing World", Romanian Journal of Economic Forecasting, 22(2), 78-97.

Ratha, D. (2004), "Workers Remittances: An Important and Stable Source of External Development Finance Global Development Finance", World Bank Working Paper, Washington D.C.

Robinson, J.C. (1952), The Generalisation of the General Theory in the Rate of Interest and Other Essays, Macmillan Press, London.

Sami, J. (2013), "Remittances, Banking Sector Development and Economic Growth in Fiji”, International Journal of Economics and Financial Issues, 3(2), 503-511.

Shahbaz, M.M. \& N. Qureshi \& N. Aamir (2007), "Remittances and Financial Sector's Performance: Under Two Alternative Approaches for Pakistan", International Research Journal of Finance and Economics, 12(1), 133-46.

Suğanlı, M. (2003), “Almanya'da Yaşayan ve Türkiye Cumhuriyet Merkez Bankası'nda Hesabı Bulunan Türklerin Sosyo Ekonomik Yapısı ve İşçi Dövizleri”, TCMB Uzmanlık Tezi, Ankara.

Tar1, R. (2011), Ekonometri, Umuttepe Yayınları, Kocaeli.

TCMB (2013), Kredi Mektuplu Döviz Tevdiat ve Süper Döviz Hesaplarına İlişkin Basın Duyurusu, <https://www.tcmb.gov.tr/wps/wcm/connect/62b993f8-8594-4a1c-b07734be685f5d55/DUY2013_72.pdf?MOD=AJPERES>, 23.03.2021.

Ugwuegbe, S.U. et al. (2018), "International Migrant Remittances and Financial Sector Development: Evidence from West African Monetary Zone (WAMZ)", Journal of International Business and Economics, 6(2), 65-72.

Yamak, R. \& A. Korkmaz (2007), "Türk Cari İşlemleri Açığı Sürdürebilir mi? Ekonometrik Bir Yaklaşım”, Bankacılar Dergisi, (60), 17-32.

Zivot, E. \& D.W.K. Andrews, (1992), "Further Evidence on the Great Crash, the Oil Price Shock and the Unit-root Hypothesis", Journal of Business and Economic Statistics, 10(3), 251-70. 